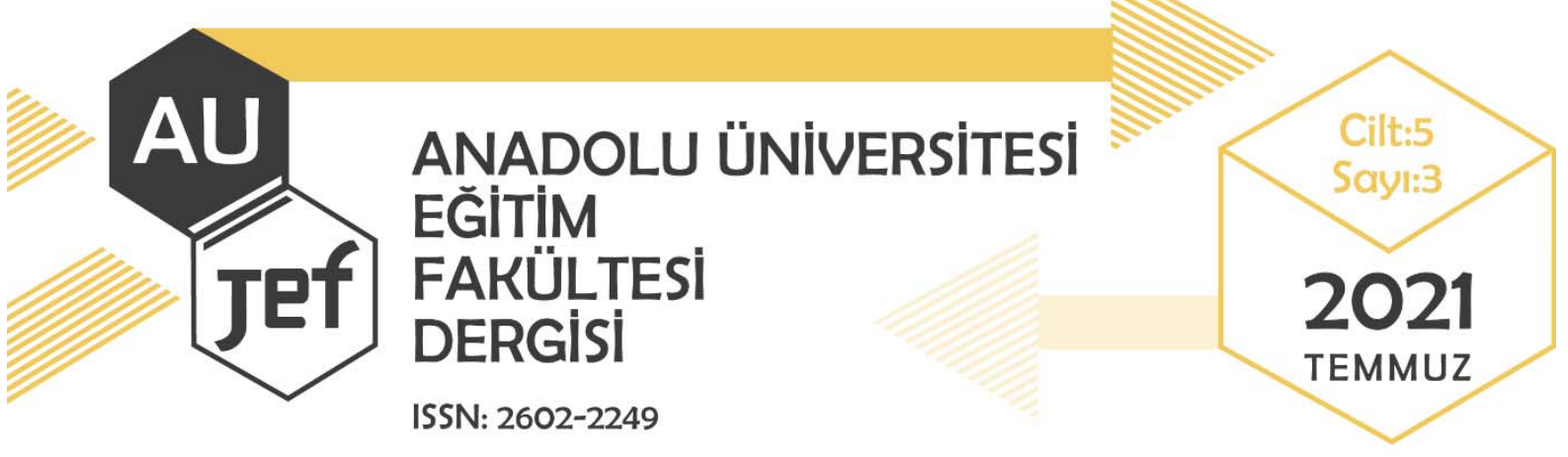

\title{
Özel Eğitim Öğrencilerinin Okuduğunu Anlama Becerilerini Geliştirmede Teknoloji Destekli Öğretimin Etkisi ${ }^{1}$
}

\section{The Effect of Technology-Supported Instruction on Improving Special Education Students' Reading Comprehension Skills ${ }^{1}$}

Nihat KAVAN ${ }^{2}$

Makale Türü: Araştırma Makalesi

Başvuru Tarihi: 24.11.2020

Kabul Tarihi: 24.06.2021

Atıf İçin: Kavan, N. (2021). Özel Eğitim Öğrencilerinin Okuduğunu Anlama Becerilerini Geliştirmede Teknoloji Destekli Öğretimin Etkisi. Anadolu Üniversitesi Eğitim Fakültesi Dergisi (AUJEF), 5(3), 264-284.

ÖZ: Yapılan bu çalışma özel eğitim öğrencilerinin okuduğunu anlama becerilerini geliştirmede teknoloji destekli öğretimin etkisini tespit etmek amacıyla gerçekleştirilmiştir. Bu amaçla deney ve kontrol gruplarından oluşan 20 hafif zihinsel gereksinimi olan 6. sınıf öğrencisinin okuduğunu anlama düzeyi nicel araştırma yöntemlerinden olan ön test-son test kontrol gruplu seçkisiz deneysel desen modeline göre tasarlanan verilerle incelenmiştir. 2018 Türkçe Dersi Öğretim Programı'nda yer alan bilgilendirici, hikâye edici ve şiir metin türlerinin alt türleri olan dokuz metin türüne uygun olarak seçilen metinler haftalık periyotlarla öğrencilere sunulmuştur. Metinler birbirine denk olan bu gruplardan deney grubu öğrencilerine etkileşimli tahta aracılığıyla kontrol grubu öğrencilerine ise akıllı tahta kullanılmadan geleneksel öğretim yöntemleri ile sunulmuştur. Metinler işlendikten sonra öğrencilere her birisi beş sorudan oluşup 100 puan üzerinden değerlendirilen Okuduğunu Anlama Başarı Testi uygulanmıştır. Yapılan en son Okuduğunu Anlama Başarı Testinin ardından iki hafta sonra Kalıcılık Testi yardımıyla öğrencilerin okudukları metinleri anlamlandırma düzeyleri analiz edilmiştir. Araştırma bulguları sonucunda, deney ve kontrol grubu öğrencilerinin ön test puanları arasında anlamlı bir fark bulunamamıştır. Fakat Kalıcılık Testi puanları karşılaştırıldığında deney grubu ve kontrol grubu ögrencilerinin puanları arasında istatistiki açıdan pozitif yönde anlamlı bir fark bulunmuştur. Araştırma sonucunda deney grubunda bulunan öğrencilerin kalıcılık testi puanlarının kontrol grubunda bulunan öğrencilerin puanlarından daha yüksek olduğu tespit edilmiştir.

Anahtar Kelimeler: Gereksinim, Okuduğunu Anlama, Özel Eğitim, Teknoloji.

ABSTRACT: This study was carried out in order to determine the effect of technology-supported education on developing special education students' reading comprehension skills. For this purpose, the reading comprehension level of 20 students with mild mental needs, consisting of experimental and control groups, was examined with the data designed according to the random experimental design model with pre-test and post-test control group. The texts selected in accordance with the nine text types in the 2018 Turkish Language Curriculum were presented to the students on a weekly basis. The texts were presented to the experimental group students from the groups

\footnotetext{
${ }^{1} \mathrm{Bu}$ çalışma, yazarın “Teknoloji Destekli Eğitimin Özel Eğitim Öğrencilerinin Okuduğunu Anlama Becerilerine Etkisi” başlıklı yüksek lisans tezinin nicel verilerinden türetilmiştir.

${ }^{2}$ Bilim Uzmanı, nihatkavan@gmail.com, ORCID: 0000-0003-4872-1002
} 
with equivalent texts via the interactive whiteboard, and the control group students by traditional teaching methods without using smartboards. After the texts were treated, the Reading Comprehension Achievement Test was applied to the students, each consisting of five questions and evaluated over 100 points. Two weeks after the last test, students' comprehension levels of the texts they read were analyzed with the help of the Retention Test. As a result of the research findings, no significant difference was found between the pre-test scores of the experimental and control group students. However, when the Retention Test scores were compared, a positive significant difference was found between the scores of the students in the experimental group and the control group. As a result of the research, it was determined that the permanence test scores of the students in the experimental group were higher than the scores of the students in the control group.

Keywords: Requirement, Reading Comprehension, Special Education, Technology. 


\section{GİRIŞ}

Dil, bireyin sahip olduğu duygu, düşünce, yaşam tarzı, hayata bakış açısının somutlaşmış hâlidir. Tanınmış araştırmacı ve bilim insanları dili bireyin içinde yaşadığı kültürün ana ögesi olarak tarif etmektedir. Son derece etkili bir kültürel aktarım aracı olan dil, sözlü ve yazılı kültüre ait ürünlerin kuşaktan kuşağa aktarılmasını sağlamaktadır (Göçer, 2012, s. 52). Dilin nesilden nesile kuşaklara aktarılması eğitim faaliyetleri ile sağlanabilmektedir. Eğitim ise ferdin içinde bulunduğu toplumda kabiliyetini, tavırlarını ve olumlu diğer davranış şekillerini geliştirdiği süreçlerin bütünüdür (Çakmak, Özdaş \& Öter, 2017). Bireyin sosyal kabiliyetinin ve bireysel gelişiminin ortaya çıkması için seçilmiş, kontrollü bir çevreyi içine alan sosyal bir süreçtir (Tezcan, 1996, s. 3).

Teknoloji hayatımızın tüm boyutlarında bulunarak bize heyecan veren, bizi şaşırtan değişiklikler ve kolaylıklar sunmaktadır. Ayrıca teknoloji, yaşamı daha kolay ve zevkli hâle getirmektedir. Pek çok insana daha sağlıklı, varlıklı bir yaşam sunarak onları daha rasyonel olmaya güdülemektedir (Kabakçı \& Odabaş1, 2004). Yaşadığımız yüzyılda her alanda kendini gösteren hızlı değişim ve gelişim, daha önce hiç görülmemiş bir hızda ilerleyen dönüşümü de beraberinde getirmektedir (Belet Boyacı ve Güner Özer, 2019, s. 710). Teknolojideki bu gelişmeler eğitim teknolojisi adı altında yeni bir alan oluşturmuş̧tur. Çoban (2012) eğitim teknolojilerini öğretmenlerin yalnızca sesini kullanmasından ziyade öğrencilerin daha verimli ve istendik öğrenmeler edineceği teknolojik aygitlar olarak tanımlamaktadır. Kuday'a (2020) göre ise eğitim teknolojisi, teknolojinin eğitim süreciyle gelişip üst seviyelere daha hızlı ve etkili çıkarak kullanılmasıdır. Yıllar boyunca sınıfta kullanılan teknolojiyi tanımlamak için çeşitli terimler kullanılmıştır. İlginç bir şekilde, kullanılan terimler genellikle zamanın teknolojisinin durumunu yansitmakta olup teknoloji yenilendikçe eğitim teknolojisinin tanımı da beraberinde değişmektedir (Lee \& Winzenried, 2009, s. 21).

Eğitim öğretim ortamlarında, 21. yüzyılda görsel öge unsurları yoğun bir şekilde kullanılmaktadır. Gerek Türkçe dersinde olsun gerek diğer derslerde olsun görseller, derslerin vazgeçilmezleri konumuna geçmiş bulunmaktadır (Akkaya, 2013, s. 478). Bu sebeple teknolojiyle desteklenen eğitim ortamları, özel gereksinimleri bulunan bireylerin yetersizliklerinin türüne uygun olarak görme, işitme, okuma, yazma, akademik, sosyal ve iletişim becerilerini desteklemektedir ve onlara bağımsız hayat becerileri kazandırmaktadır. Söz konusu kişilerin amaçlanan bilgiyi kolayca, kalıcı ve hızı bir biçimde öğrenmesine imkân vermektedir. Türk eğitim sisteminde özel eğitim faaliyetlerine yönelik araştırmaların artması ve gelişmesi ile özel eğitime yönelik araştırmalar da artmıştır (Özdemir, Kisaç, Ünlü \& Kaplan, 2020).

Teknoloji ve eğitimin ilişkisinin giderek yaygınlaştığı günümüzde bilgi ve teknoloji giderek gelişme göstermektedir. Dünya geneline bakıldığında eğitim politikalarında teknoloji ile birlikte birçok değişim ve gelişim gözlenmekte, bununla birlikte proje çalışmaları hız kazanmaktadır (Demir, 2019, s. 21). Ülkemizde de Fırsatları Arttırma Teknolojiyi İyileştirme Hareketi Projesi (FATİH) olarak adlandırılan söz konusu eğitim teknolojileri projesi Millî Eğitim Bakanlığı (MEB) tarafından 2010 yılında uygulamaya konulmuştur (Hiçyılmaz \& Kayserili, 2017, s. 58).

Hayat boyunca gelişip ilerleyerek devam eden bir süreç olan eğitim, toplumun ihtiyaçları doğrultusunda şekillenmekte ve sistematik bir şekilde sürdürülmektedir (Göksu \& Gülcü, 2016, s. 154). Eğitim teknolojilerindeki gelişmeler eğitim kurumlarında bulunan tüm öğrencileri etkilemekle beraber özel gereksinimli bireyleri de olumlu yönde etkilemektedir. Özel gereksinimli bireylerin akranlarına göre eğitim olanaklarından faydalanması ve verim alması güç bir durum olduğu için kendilerine özgü eğitim ortamları tasarlanmaktadır. Özel eğitime gereksinim duyan fertlerin eğitim gereksinimlerini karşılamak üzere özel olarak yetiştirilen görevliler, geliştirilen eğitim programlarıyla ve yöntemleriyle 
bu bireylerin gereksinimlerine ve özelliklerine uygun atmosferde devam ettirilen eğitim çeşidine özel eğitim denmektedir (MEB, 2010, s. 6). Özel eğitim, ortalama olarak tespit edilmiş özelliklerden farklı özellikleri bulunan bireylerin, bağımsız olarak hayatlarını devam ettirmesini temin etmek için verilmiş olan eğitim hizmetidir (Şanal, Güler, \& Erdem, 2018, s. 408). Kişiler; bedensel, zihinsel, duyuşsal ve toplumsal olarak değişik gelişimsel özelliklere sahip olabilmektedir. Kimileri iletişim, gündelik etkinlikleri yerine getirme, öğrenme ve çevrelerine uymada güçlükle sonuçlanan gelişimsel engellerle karşılaşabilmektedir. Özel eğitim, bu durumdaki kişilerin davranışlarıyla hayatlarını iyileştirmek üzere uygun eğitim tecrübeleri temin etmek gibi bir fonksiyonu üstlenmektedir (Subakan \& Koç, 2019, s. 51).

Bireyler fiziksel, zihinsel, sosyal ve duyuşsal olarak birbirinden değişik gelişimler sergilemektedir. Bireylerin bir kısmı iletişimde, gündelik etkinlikleri gerçekleştirmede, öğrenmede ve çevreye uyum sağlamada zorluklara neden olan gelişimsel engeller ile karşı karşıya kalmaktadır. Özel eğitim, bu tür bireylerin davranışlarıyla yaşamlarını daha iyi hâle getirmek üzere uygun eğitim tecrübeleri oluşturmak gibi zor bir göreve sahiptir. Ancak teknoloji, kişisel öğrenmeyi özendirmekte ve değişik gereksinimleri bulunan kişiler için farklı fırsatlar oluşturmaktadır. Kaplan ve Çifci Tekinarslan'a (2013) göre özel eğitime gereksinim duyan öğrencilere sunulan eğitim faaliyetlerinin uygun kaynak, araç gereç ve teknolojilerle desteklenmesi gerekmektedir.

Türkçe dersi disiplinler arası bir model olmaya uygun olmakta ve tüm derslerle doğrudan veya dolaylı olarak ilişkilidir. Tüm disiplinlerin bilgi tabanları ve bu bilgi tabanlarında kullanılan araçlar ve yöntemler değişebilmektedir (Çakmak, Özdaş \& Akın, 2020, s. 439). Türkçe dersi ise bireyin sadece düşündüklerini, okuduklarını aktarabilmesi değil aynı zamanda okuduklarını tam ve doğru anlama becerilerini kazandırmayı amaçlamaktadır (Evran Acar, 2010, s. 92). Okuduğunu anlama becerisinin öneminin artması ile Türkçe eğitiminde de farklı araçlar ve yöntemlerle teknoloji destekli öğretimden faydalanılması ve bu yöndeki çalışmaların arttırılması gereklilik olmuştur. Okuduğunu anlama becerisinin gelişmesinde tecrübe kazanılması ve teorik bilgilerin öğrenme ortamında test edilebilmesi için pratik süreçler gerekmektedir (Özdaş \& Çakmak, 2018, s. 2761). Günümüzde özel eğitime ihtiyaç duyan çocuklar için özel eğitim birimleri açılmakta ve artmaktadır. Bu durum akademik çalışmalara olan ihtiyacı da beraberinde getirmiştir. Ana dili Türkçe olan bu öğrencilerin daha yetkin ve modern eğitim şartlarında yetiştirilmesi önem arz etmiştir. Bu çalışmanın da amacı özel eğitim alan hafif zihinsel gereksinim olan 6. sınıf öğrencilerinin teknoloji destekli öğretim yardımıyla okuduğunu anlama becerilerini araştırmaktır. Disiplinler arası modelle hazırlanan bu çalışmada hazırlanmış olan teknoloji destekli öğretim materyallerinin deney grubu öğrencilerine sunularak kontrol grubu öğrencileri ile aralarında anlamlı bir farklılaşma olup olmadığının tespit edilmesi amaçlanmıştır.

Yapılan bu araştırma özel eğitim öğrencilerinin okuduğunu anlama becerilerini geliştirmede teknoloji destekli öğretimin ne düzeyde etkili olduğunu tespit etmek amacıyla gerçekleştirilmiştir. Bu amaçla hafif zihinsel gereksinimi olan 6. sınıf öğrencilerinden meydana gelen çalışma grubunun okuduğunu anlama düzeyine teknoloji destekli öğretimin etkisi sınanmaya çalışılmıştır. Araştırmada “Özel eğitim öğrencilerinin okuduğunu anlama becerilerini geliştirmede teknoloji destekli öğretimin etkisi ne düzeydedir?" sorusuna ve aşağıdaki alt problemlere cevap aranmıştır:

1. Deney ve kontrol grubuna dâhil olan öğrencilerin okuduğunu anlama ön test ve kalıcılık testi puanları arasinda fark var midir?

2. Deney ve kontrol grubuna dâhil olan öğrencilerin okuduğunu anlama ön test sonuçları öğrencilerin demografik özelliklerine göre farkl1lık göstermekte midir?

3. Deney ve kontrol grubundaki öğrencilerin okuduklarını anlama kalıcılık testi sonuçları öğrencilerin demografik özelliklerine göre farkl1lık göstermekte midir? 
4. Deney ve kontrol grubundaki öğrencilerin okuduğunu anlama ön testindeki puanlarına uygun olarak düzeltilen kalıcılık testindeki puanları anlamlı bir biçimde farklılaşmakta mıdır?

5. Deney ve kontrol grubundaki öğrencilerin okuduğunu anlama ön testindeki puanlarına uygun olarak metin türlerinin ön test puanları anlamlı bir biçimde farklılaşmakta mıdır?

Bu araştırma, 2019-2020 eğitim-öğretim yılında Mardin ilinin Kızıltepe ilçesindeki Mehmet Akif İnan Ortaokulu ve Zergan Ortaokulunun özel eğitim sınıflarında öğrenim gören 6. sınıf öğrencileri ile sınırlıdır. Araştırma 2018 Türkçe Dersi Öğretim Programı'nda yer alan bilgilendirici, hikâye edici ve şiir türlerinin alt türleri olan 9 metin türü (Terleyince, Geyik ile Kaplan, Adsız Çeşme, Doğuran Kazan, Ağustos Böceği ve Karınca, Kitabım, Atatürk, Gökçen Kız Çeşmesi, Mevsimler) ve bu metinlere ilişkin olarak oluşturulan ölçme araçları ile sınırlıdır.

\section{YÖNTEM}

\subsection{Araştırmanın Modeli}

Özel eğitim öğrencilerinin okuduğunu anlama becerilerini geliştirmede teknoloji destekli öğretimin etkisinin incelendiği bu araştırma nicel araştırma yöntemlerinden olan ön test-son test kontrol gruplu seçkisiz deneysel desen modeline göre tasarlanmıştır. Fraenkel ve Wallen'e (2006) göre deneysel araştırmayı diğer yöntemlere göre eşsiz kılan iki husus şunlardır: Birincisi, bir değişkenin etkilerini gözlemede kullanılabilecek tek yoldur. İkincisi ise uygun kullanıldığında neden ve sonuç ilişkilerini test eden en geçerli ve güvenilir yoldur. Split-plot desen veya karışı desen olarak da tanımlanabilen ön test-son test kontrol gruplu desen, birisi tekrarlı ölçümleri (ön test-son test), diğeri de farklı kategorilerde bulunan denekleri (deney-kontrol gruplarını) gösteren iki faktörlü bir deneysel desen olarak belirtilmektedir (Büyüköztürk, 2001). Kullanılan desenin simgesel gösterimine Tablo 1'de yer verilmiştir.

Tablo 1. Araştırma Desenine Iliş̧kin Simgeler

\begin{tabular}{|c|c|c|c|}
\hline Çalışma Grubu & Uygulama Öncesi & Süreç & Uygulama Sonrası \\
\hline $\begin{array}{l}\text { D } \\
10 \text { Öğrenci } \\
\text { (Deney Grubu) }\end{array}$ & $\begin{array}{l}\text { Öğretmen Veri Formu } \\
\text { Öğrenci Veri Formu } \\
\mathrm{M}_{1} \text {. Terleyince } \\
\mathrm{M}_{2} \text {. Geyik ile Kaplan } \\
\mathrm{M}_{3} \text {. Adsız Çeşme } \\
\mathrm{M}_{4} \text {. Doğuran Kazan } \\
\mathrm{M}_{5} \text {. Ağustos Böceği ve Karınca } \\
\mathrm{M}_{6} \text { Kitabım } \\
\mathrm{M}_{7} \text { Atatürk } \\
\mathrm{M}_{8} \text {. Gökçen Kız Çeşmesi } \\
\mathrm{M}_{9} \text { Mevsimler }\end{array}$ & $\begin{array}{c}\text { Teknoloji Destekli } \\
\text { Uygulamalara Dayalı } \\
\text { Öğretim }\end{array}$ & $\begin{array}{c}\text { Okuduğunu Anlama } \\
\text { Başarı Testi } \\
\text { Kalıcılık Testi }\end{array}$ \\
\hline $\begin{array}{l}\text { K } \\
10 \text { Öğrenci } \\
\text { (Kontrol Grubu) }\end{array}$ & $\begin{array}{l}\text { Öğretmen Veri Formu } \\
\text { Öğrenci Veri Formu } \\
\mathrm{M}_{1} \text {. Terleyince } \\
\mathrm{M}_{2} \text {. Geyik ile Kaplan } \\
\mathrm{M}_{3} \text {. Adsız Çeşme } \\
\mathrm{M}_{4} \text {. Doğuran Kazan } \\
\mathrm{M}_{5} \text {. Ağustos Böceği ve Karınca } \\
\mathrm{M}_{6} \text { Kitabım } \\
\mathrm{M}_{7} \text { Atatürk } \\
\mathrm{M}_{8} \text {. Gökçen Kız Çeşmesi } \\
\mathrm{M}_{9} \text { Mevsimler }\end{array}$ & Geleneksel Öğretim & $\begin{array}{c}\text { Okuduğunu Anlama } \\
\text { Başarı Testi } \\
\text { Kalıcılık Testi }\end{array}$ \\
\hline
\end{tabular}




\section{2. Çalışma Grubu}

Araştırmanın çalışma grubunu 2019-2020 eğitim öğretim yılında Mardin ili Kızıltepe ilçesinin iki farklı ortaokulunda 6. sınıf öğrenimine devam eden ve özel eğitim sınıflarında öğrenim gören 20 öğrenci oluşturmaktadır. Okullardan birisinin öğrencileri deney grubu olarak, diğer okulun öğrencileri ise kontrol grubu olarak belirlenmiştir. Her grupta 10 öğrenci olmak üzere toplam 20 öğrenci araştırmaya dâhil edilmiştir. Özel eğitim sınıflarında en fazla 10 öğrenci bulunmaktadır. Her 5 öğrenciden de 1 öğretmen sorumlu olup her sinıfta 2 özel eğitim öğretmeni görev yapmaktadır (MEB, 2020, s. 7). Her iki gruptaki öğrenciler de hafif zihinsel gereksinimi olan ortaokul grubu düzeyindedir. Çalışmanın yürütüleceği okulların belirlenmesinde ölçüt örnekleme yöntemi kullanılmıştır. Ölçüt örnekleme yöntemi ile araştırmaya katılan bireyler seçilirken örneklemi belirleyen olguyu karşılayabilen kişilerden seçilir (Canbazoğlu Bilici, 2019). Ölçüt örnekleme yönteminde, çalışmayı gerçekleştiren bireylerce daha önceden belirlenmiş ölçütlerin karşılanması önemli bir noktadır (Patton, 2014). Bu bağlamda yapılan araştırmada etkileşimli tahtanın aktif kullanılması, araştırmanın gerçekleştirileceği sınıflarda görevli öğretmenlerin mesleki tecrübelerinin en az 4 yıl olması ve gönüllü olması, araştırmaya katılan öğrencilerin gereksinim durumlarının benzer olması ve araştırmanın gerçekleştirileceği okulların kolay ulaşılabilir konumda olması çalışma grubunun belirlenmesindeki ölçütler olarak belirlenmiştir. Özel eğitim sınıflarında öğrenim gören öğrenciler içerisinden araştırmaya konu olacak deney ve kontrol gruplarının belirlenmesinde ise tesadüfi yöntem kullanılmıştır. Deney (D) ve kontrol (K) grubu öğrencilerine yönelik elde edilen kişisel veriler Tablo 2'de sunulmuştur.

Tablo 2. Deney ve Kontrol Grubu Verileri

\begin{tabular}{lcccccc}
\hline Öğrenci & Yaş & Cinsiyet & $\begin{array}{c}\text { Öğrenciyle Aynı } \\
\text { Evde Yaşayan Kişi } \\
\text { Sayısı }\end{array}$ & $\begin{array}{c}\text { Kardeş } \\
\text { Sayıs }\end{array}$ & $\begin{array}{c}\text { Ailede Özel } \\
\text { Eğitim Alan } \\
\text { Başka Bireyler }\end{array}$ & $\begin{array}{c}\text { Kişiye Ait } \\
\text { Teknolojik } \\
\text { Cihaz }\end{array}$ \\
\hline $\mathrm{D}_{1}$ & 16 & $\mathrm{~K}$ & 8 & 6 & & \\
$\mathrm{D}_{2}$ & 13 & $\mathrm{~K}$ & 5 & 3 & & \\
$\mathrm{D}_{3}$ & 12 & $\mathrm{E}$ & 5 & 3 & & \\
$\mathrm{D}_{4}$ & 16 & $\mathrm{E}$ & 5 & 3 & & \\
$\mathrm{D}_{5}$ & 13 & $\mathrm{~K}$ & 7 & 5 & & \\
$\mathrm{D}_{6}$ & 12 & $\mathrm{E}$ & 7 & 5 & & \\
$\mathrm{D}_{7}$ & 12 & $\mathrm{~K}$ & 11 & 3 & & \\
$\mathrm{D}_{8}$ & 12 & $\mathrm{E}$ & 5 & 3 & & \\
$\mathrm{D}_{9}$ & 13 & $\mathrm{~K}$ & 5 & 3 & & \\
$\mathrm{D}_{10}$ & 12 & $\mathrm{E}$ & 7 & 5 & & \\
$\mathrm{~K}_{1}$ & 14 & $\mathrm{~K}$ & 7 & 5 & & \\
$\mathrm{~K}_{2}$ & 13 & $\mathrm{E}$ & 8 & 6 & & \\
$\mathrm{~K}_{3}$ & 15 & $\mathrm{E}$ & 5 & 3 & & \\
$\mathrm{~K}_{4}$ & 15 & $\mathrm{E}$ & 5 & 3 & & \\
$\mathrm{~K}_{5}$ & 12 & $\mathrm{E}$ & 5 & 3 & & \\
$\mathrm{~K}_{6}$ & 14 & $\mathrm{E}$ & 6 & 4 & & \\
$\mathrm{~K}_{7}$ & 11 & $\mathrm{E}$ & 8 & 6 & & \\
$\mathrm{~K}_{8}$ & 12 & $\mathrm{~K}$ & 6 & 4 & & \\
$\mathrm{~K}_{9}$ & 14 & $\mathrm{~K}$ & 7 & 5 & & \\
$\mathrm{~K}_{10}$ & 13 & $\mathrm{~K}$ & 9 & 7 & & \\
\hline & & & & & & \\
\end{tabular}




\subsection{Veri Toplama Araçları}

Deney ve kontrol grubu öğrencileri için 2018 Türkçe Dersi Öğretim Programı'nda yer alan bilgilendirici, hikâye edici ve şiir metin türlerinin alt türleri olan 9 türe ait metinler (Terleyince, Geyik ile Kaplan, Adsız Çeşme, Doğuran Kazan, Ağustos Böceği ve Karınca, Kitabım, Atatürk, Gökçen Kız Çeşmesi, Mevsimler) haftalık periyotlarla hem deney grubu öğrencilerine hem kontrol grubu öğrencilerine sunulmuştur. Metinler ve okuduğunu anlama başarı testleri (OABT); ders kitapları, yardımcı kaynaklar, alanyazında yapılan benzer çalışmalar taranarak seçilmiştir. Metinlerin seçiminde ve OABT'lerin hazırlanmasında; Türkçe eğitimi alanından iki doçent öğretim üyesinin, eğitim bilimleri alanından bir doçent ve bir doktor öğretim üyesinin, özel eğitim alanından bir doktor öğretim üyesinin ve çalışmanın birlikte yürütüleceği özel eğitim öğretmenlerinin görüşleri alınarak metinlerin ve OABT'lerin öğrencilerin seviyesine ve algı düzeyine uygunlukları hakkında bilgi alınmıştır. Eğitim materyalleri, deney grubu öğrencilerine etkileşimli tahta aracılı̆̆ıyla, kontrol grubu öğrencilerine ise etkileşimli tahta kullanılmadan geleneksel öğretim yöntemleri ile sunulmuştur. Belirlenen metinlerle dersler işlendikten sonra öğrencilere her metin için ayrı ayrı hazırlanan OABT uygulanmıştır. Belirlenen sürede başlayan ve biten çalışmalar son testin ardından iki hafta sonra yapılan kalıcılık testi yardımı ile öğrencilerin okudukları metinleri anlamlandırma düzeyleri tespit edilmeye çalışılmıştır.

OABT ve kalıcılık testlerinin hazırlanıp değerlendirilmesinde ölçme ve değerlendirme uzmanlarının görüş ve önerilerine başvurularak testlere son hâlleri verilmiştir.

\subsubsection{Okuduğunu Anlama Başarı Testi (OABT)}

Araştırmaya konu olan metin türlerine yönelik geri bildirim almak ve ön test oluşturmak için beş soruluk OABT hazırlanmıştır. Her bir test metin ile ilgili beş sorudan oluşmaktadır. Testlerde yer alan sorulardan her biri 20 puan olmak üzere testler 100 puan üzerinden değerlendirilmiştir. Testlerde yer alan sorular çoktan seçmeli, kısa cevaplı, açık uçlu ve görsel çizime imkân sağlayacak türde karma niteliklidir. Bu şekilde öğrencilerin tek bir soru türü ile sıkılmamaları ve farklı soru türlerini de çözme becerileri dolaylı olarak ölçmek amaçlanmıştır. Bunun bir diğer amacı ise araştırmacının hazırlanan OABT'leri geliştirme çalışmasıdır.

\subsubsection{Kalıcıllk Testi}

Yapılan araştırmanın ön test verilerinin zamana karşı dirençlerini ölçmek amacıyla ön test metinlerinden oluşturulan OABT'lerden kalıcılık testi oluşturulmuştur. Kalıcılık testi, 10 sorudan oluşmaktadır ve her soru 10 puan üzerinden değerlendirilmek üzere 100 puan olacak şekilde tasarlanmıştır. Sorular, ön test verilerini oluşturan 9 OABT'den seçilmiştir. Her OABT'den bir soru seçilmiş, onuncu soru olarak ise öğrencilerin duyuş algılarına hitap eden bir soru eklenmiştir. Kalıcılık testi de OABT gibi karma yapılı soru türlerinden seçilmiştir. Kalıcılık testinin, gerçek anlamda zamana karşı direncini ölçmek için dört haftalık bir süreç gerekmektedir. Fakat çalışma grubunun hafif zihinsel gereksinimli ögrencilerden oluşması sebebiyle uzman görüşlerine başvurulduktan sonra metinlerin işlenmesinden iki hafta sonra kalıcılık testinin uygulanması kararlaştırılmıştır.

\subsection{Verilerin Toplanması}

Yapılan araştırmada veri toplama öncesinde ortaokul seviyesinde özel eğitim sınıfı bulunan tüm okullara gidilerek araştırma yapılmıştır. Özel eğitim sınıfı bulunan okul sayısının az olması ve sınıfların özel gereksinim durumları ile özel gereksinim dereceleri birbirinden farklı olduğu için araştırmanın bir okulda yürütülmesi mümkün olmamıştır. Araştırılacak öğrencilerin ortaokul grubu, hafif zihinsel gereksinimi olan özel eğitim sınıfında okumaları gerekliliği kapsamı daraltmıştır. Araştırmacı 
tarafindan geliştirilen Öğretmen Veri Formu ve Öğrenci Veri Formu analizleri sonucunda şartları birbirine yakın iki okul tespit edilmiştir. Deney ve kontrol grupları uygulama öncesinde belirlendikten sonra deney grubunda teknoloji destekli uygulamalara dayalı öğretim, kontrol grubunda ise geleneksel öğretim yöntemleri ile öğretim yapılmıştır. Uygulamaya geçilmeden önce araştırmanın gerçekleştirileceği sınıflarda görev yapan öğretmenlere deneysel süreç öncesi uygulamaya ilişkin bilgi ve eğitimler verilmiştir.

Veri toplama amacıyla 2018 Türkçe Dersi Öğretim Programı'nda yer alan metin türleri esas alınarak hazırlanan okuduğunu anlamaya dayalı metinler kullanılmıştır. Deney ve kontrol grupları farklı okullarda bulundukları için metinler birer gün arayla işlenmiştir. Haftalık periyotlar ve farklı günlerde yapılan uygulamalar ders öğretmenleri tarafından özel eğitim sınıflarında yapılmıştır.

\subsection{Verilerin Analizi}

Araştırma kapsamında toplanan nicel veriler IBM SPSS 25.00 paket yazılımı kullanılarak analize tabi tutulmuştur. Araştırmada, katılımcıların demografik özelliklerini ortaya koymak amacıyla betimsel istatistik analizlerinden frekans analizinden ve standart sapmadan faydalanılmıştır. Ayrıca araştırma kapsamında kurgulanan desendeki kontrol grubu ve deney grubundaki öğrencilerin ön test ve kalıcılık testi puanlarının karşılaştırılması amacıyla ilişkisiz örneklem t-testi, tek faktörlü varyans analizi (OneWay Anova) uygulanmıştır.

İstatistiki analizlere geçmeden önce deney ve kontrol gruplarının bağımlı değişkene ait puanlarının evrendeki dağılım normalliğini sınamak amacıyla Kolmogorov-Smirnov (K-S) testi gerçekleştirilmiş ve sonuçları Tablo 3 'te verilmiştir.

Tablo 3. Deney ve Kontrol Gruplarının Ölçek Puanlarının Evrendeki Dağılım Sonuçları

\begin{tabular}{lcc}
\hline Ölçek & $\mathbf{Z}$ & $\mathbf{p}$ \\
\hline Terleyince & .997 & .27 \\
Geyik ve Kaplan & 1,203 & .11 \\
Adsız Çeşme & 1,248 & .09 \\
Doğuran Kazan & .812 & .52 \\
Ağustos Böceği ile Karınca & .967 & .31 \\
Kitabım & .825 & .51 \\
Atatürk & .868 & .44 \\
Gökçen Kız Çeşmesi & .679 & .75 \\
Mevsimler & .678 & .75 \\
\hline
\end{tabular}

$N=20, p>.05$

Tablo 3 incelendiğinde, deney ve kontrol gruplarının ön test sonuçlarına ait puanların evrendeki dağılımının normal dağılımdan anlamlı farklılık göstermediği gözlenmektedir. Analiz sonucuna göre pdeğerinin .05 'ten büyük çıkması, demokratik tutum puanlarının normal dağılımdan anlamlı sapma göstermediğini göstermektedir. 


\section{BULGULAR}

\subsection{Araştırmadaki Ön Test Sonuçlarına İlişkin Bulgular}

Deney ve kontrol gruplarındaki öğrencilerin Terleyince (Ertuna, 2019), Geyik ile Kaplan (Kanar, 2009), Adsız Çeşme (Ağın Haykır, Kaplan, Kıryar, Tarakçı, \& Üstün, 2018), Doğuran Kazan (Şirin, 2011), Ağustos Böceği ve Karınca (La Fontaine, 2011), Kitabım (Dağlarca, 2012), Atatürk (Ataşçi, 2019), Gökçen Kız Çeşmesi (Ertuna, 2019) ve Mevsimler (Atak, 2019) isimli metinlerden okuduklarını anlama ve anlamlandırma düzeylerine ilişkin ortalama puanları Tablo 4'te sunulmuştur.

Tablo 4. Metinlerin Okuduğunu Anlama Ön Test Puanları

\begin{tabular}{|c|c|c|c|c|c|c|c|}
\hline Metin & Çalışma Grupları & $\mathbf{n}$ & $\begin{array}{c}\text { Ön Test } \\
\bar{x} \\
\end{array}$ & $\begin{array}{c}\text { Ön Test } \\
\text { Ss }\end{array}$ & df & $\mathbf{t}$ & $\mathbf{p}$ \\
\hline \multirow{2}{*}{ Terleyince } & Kontrol Grubu & 10 & 35,0 & 10,80 & \multirow{2}{*}{18} & \multirow{2}{*}{-.753} & \multirow{2}{*}{.46} \\
\hline & Deney Grubu & 10 & 39,0 & 12,86 & & & \\
\hline \multirow{2}{*}{ Geyik ile Kaplan } & Kontrol Grubu & 10 & 51,0 & 21,31 & \multirow{2}{*}{18} & \multirow{2}{*}{-.750} & \multirow{2}{*}{.47} \\
\hline & Deney Grubu & 10 & 58,0 & 20,43 & & & \\
\hline \multirow{2}{*}{ Adsız Çeşme } & Kontrol Grubu & 10 & 51,0 & 19,12 & \multirow{2}{*}{18} & \multirow{2}{*}{-.649} & \multirow{2}{*}{.53} \\
\hline & Deney Grubu & 10 & 57,0 & 22,13 & & & \\
\hline \multirow{2}{*}{ Doğuran Kazan } & Kontrol Grubu & 10 & 47,0 & 13,37 & \multirow{2}{*}{18} & \multirow{2}{*}{$-1,226$} & \multirow{2}{*}{.24} \\
\hline & Deney Grubu & 10 & 56,0 & 18,97 & & & \\
\hline \multirow{2}{*}{$\begin{array}{l}\text { Ağustos Böceği ve } \\
\text { Karınca }\end{array}$} & Kontrol Grubu & 10 & 47,0 & 18,89 & \multirow{2}{*}{18} & \multirow{2}{*}{-.624} & \multirow{2}{*}{.54} \\
\hline & Deney Grubu & 10 & 52,0 & 16,87 & & & \\
\hline \multirow{2}{*}{ Kitabım } & Kontrol Grubu & 10 & 47,0 & 13,37 & \multirow{2}{*}{18} & \multirow{2}{*}{-.296} & \multirow{2}{*}{.77} \\
\hline & Deney Grubu & 10 & 49,0 & 16,63 & & & \\
\hline \multirow{2}{*}{ Atatürk } & Kontrol Grubu & 10 & 47,0 & 18,88 & \multirow{2}{*}{18} & \multirow{2}{*}{-.373} & \multirow{2}{*}{.71} \\
\hline & Deney Grubu & 10 & 50,0 & 16,99 & & & \\
\hline \multirow{2}{*}{$\begin{array}{l}\text { Gökçen K1z } \\
\text { Çeşmesi }\end{array}$} & Kontrol Grubu & 10 & 46,0 & 20,11 & \multirow{2}{*}{18} & \multirow{2}{*}{-.578} & \multirow{2}{*}{.57} \\
\hline & Deney Grubu & 10 & 51,0 & 18,52 & & & \\
\hline \multirow{2}{*}{ Mevsimler } & Kontrol Grubu & 10 & 50,0 & 20,00 & \multirow{2}{*}{18} & \multirow{2}{*}{-.688} & \multirow{2}{*}{.50} \\
\hline & Deney Grubu & 10 & 56,0 & 18,97 & & & \\
\hline
\end{tabular}

$N=20$

Tablo 4 incelendiğinde deney grubunun Terleyince metninden okuduğunu anlama ve anlamlandırma düzeyine yönelik elde ettiği ortalama puan 39,0 olarak tespit edilmiştir. Kontrol grubuna ait puan ortalaması ise 35,0 olarak tespit edilmiştir. Deney ve kontrol gruplarının ön test bilgi düzeyi ortalamalarının anlamlı bir şekilde farklılaşmadığı yapılan t-testi sonucunda görülmüştür. Deney ve kontrol gruplarının ortalamaları arasındaki farklılık istatistiki olarak anlamlı bulunmamıştır ( $>$ >.05). Elde edilen t-testi bulgularına göre deney grubu ve kontrol grubunun Terleyince metninden okuduklarını anlama ve anlamlandırma düzeyinin denk olduğu söylenebilir.

Tablo 4 incelendiğinde deney grubunun Geyik ile Kaplan metninden okuduğunu anlama ve anlamlandırma düzeyine yönelik elde ettiği ortalama puan 58,0 olarak tespit edilmiş̧tir. Kontrol grubuna ait puan ortalaması ise 51,0 olarak tespit edilmiştir. Deney ve kontrol gruplarının ön test bilgi düzeyi ortalamalarının anlamlı bir şekilde farklılaşmadığı yapılan t-testi sonucunda görülmüştür. Deney ve kontrol gruplarının ortalamaları arasındaki farklılık istatistiki olarak anlamlı bulunmamıştır ( $\mathrm{p}>.05)$. 
Elde edilen t-testi bulgularına göre deney grubu ve kontrol grubunun Geyik ile Kaplan metninden okuduklarını anlama ve anlamlandırma düzeyinin denk olduğu söylenebilir.

Tablo 4 incelendiğinde deney grubunun Adsız Çeşme metninden okuduğunu anlama ve anlamlandırma düzeyine yönelik elde ettiği ortalama puan 57,0 olarak tespit edilmiştir. Kontrol grubuna ait puan ortalaması ise 51,0 olarak tespit edilmiştir. Deney ve kontrol gruplarının ön test bilgi düzeyi ortalamalarının anlamlı bir şekilde farklılaşmadığı yapılan t-testi sonucunda görülmüştür. Deney ve kontrol gruplarının ortalamaları arasındaki farklılık istatistiki olarak anlamlı bulunmamıştır ( $>$ >.05). Elde edilen t-testi bulgularına göre deney grubu ve kontrol grubunun Adsız Çeşme metninden okuduklarını anlama ve anlamlandırma düzeyinin denk olduğu söylenebilir.

Tablo 4 incelendiğinde deney grubunun Doğuran Kazan metninden okuduğunu anlama ve anlamlandırma düzeyine yönelik elde ettiği ortalama puan 56,0 olarak tespit edilmiştir. Kontrol grubuna ait puan ortalaması ise 47,0 olarak tespit edilmiştir. Deney ve kontrol gruplarının ön test bilgi düzeyi ortalamalarının anlamlı bir şekilde farklılaşmadığı yapılan t-testi sonucunda görülmüştür. Deney ve kontrol gruplarının ortalamaları arasındaki farklılık istatistiki olarak anlamlı bulunmamıştır ( $>$ >.05). Elde edilen t-testi bulgularına göre deney grubu ve kontrol grubunun Doğuran Kazan metninden okuduklarını anlama ve anlamlandırma düzeyinin denk olduğu söylenebilir.

Tablo 4 incelendiğinde deney grubunun Ağustos Böceği ve Karınca metninden okuduğunu anlama ve anlamlandırma düzeyine yönelik elde ettiği ortalama puan 47,0 olarak tespit edilmiştir. Kontrol grubuna ait puan ortalaması ise 52,0 olarak tespit edilmiştir. Deney ve kontrol gruplarının ön test bilgi düzeyi ortalamalarının anlamlı bir şekilde farklılaşmadığı yapılan t-testi sonucunda görülmüştür. Deney ve kontrol gruplarının ortalamaları arasındaki farklılık istatistiki olarak anlamlı bulunmamıştır ( $p>.05)$. Elde edilen t-testi bulgularına göre deney grubu ve kontrol grubunun Ağustos Böceği ve Karınca metninden okuduklarını anlama ve anlamlandırma düzeyinin denk olduğu söylenebilir.

Tablo 4 incelendiğinde deney grubunun Kitabım metninden okuduğunu anlama ve anlamlandırma düzeyine yönelik elde ettiği ortalama puan 49,0 olarak tespit edilmiştir. Kontrol grubuna ait puan ortalaması ise 47,0 olarak tespit edilmiştir. Deney ve kontrol gruplarının ön test bilgi düzeyi ortalamalarının anlamlı bir şekilde farklılaşmadığı yapılan t-testi sonucunda görülmüştür. Deney ve kontrol gruplarının ortalamaları arasındaki farklılık istatistiki olarak anlamlı bulunmamıştır ( $>$ >.05). Elde edilen t-testi bulgularına göre deney grubu ve kontrol grubunun Kitabım metninden okuduklarını anlama ve anlamlandırma düzeyinin denk olduğu söylenebilir.

Tablo 4 incelendiğinde deney grubunun Atatürk metninden okuduğunu anlama ve anlamlandırma düzeyine yönelik elde ettiği ortalama puan 49,0 olarak tespit edilmiştir. Kontrol grubuna ait puan ortalamas1 ise 50,0 olarak tespit edilmiştir. Deney ve kontrol gruplarının ön test bilgi düzeyi ortalamalarının anlamlı bir şekilde farklılaşmadığı yapılan t-testi sonucunda görülmüştür. Deney ve kontrol gruplarının ortalamaları arasındaki farklılık istatistiki olarak anlamlı bulunmamıştır ( $>$ >.05). Elde edilen t-testi bulgularına göre deney grubu ve kontrol grubunun Atatürk metninden okuduklarını anlama ve anlamlandırma düzeyinin denk olduğu söylenebilir.

Tablo 4 incelendiğinde deney grubunun Gökçen Kız Çeşmesi metninden okuduğunu anlama ve anlamlandırma düzeyine yönelik elde ettiği ortalama puan 46,0 olarak tespit edilmiştir. Kontrol grubuna ait puan ortalaması ise 51,0 olarak tespit edilmiştir. Deney ve kontrol gruplarının ön test bilgi düzeyi ortalamalarının anlamlı bir şekilde farklılaşmadığı yapılan t-testi sonucunda görülmüştür. Deney ve kontrol gruplarının ortalamaları arasındaki farklılık istatistiki olarak anlamlı bulunmamıştır ( $\mathrm{p}>.05)$. 
Elde edilen t-testi bulgularına göre deney grubu ve kontrol grubunun Gökçen Kız Çeşmesi metninden okuduklarını anlama ve anlamlandırma düzeyinin denk olduğu söylenebilir.

Tablo 4 incelendiğinde deney grubunun Mevsimler metninden okuduğunu anlama ve anlamlandırma düzeyine yönelik elde ettiği ortalama puan 56,0 olarak tespit edilmiştir. Kontrol grubuna ait puan ortalaması ise 50,0 olarak tespit edilmiştir. Deney ve kontrol gruplarının ön test bilgi düzeyi ortalamalarının anlamlı bir şekilde farklılaşmadığı yapılan t-testi sonucunda görülmüştür. Deney ve kontrol gruplarının ortalamaları arasındaki farklılık istatistiki olarak anlamlı bulunmamıştır ( $>$ >.05). Elde edilen t-testi bulgularına göre deney grubu ve kontrol grubunun Mevsimler metninden okuduklarını anlama ve anlamlandırma düzeyinin denk olduğu söylenebilir.

\subsection{Kalıcılık Testi Puanlarının Karşılaştırılması}

Deney ve kontrol gruplarındaki öğrencilerin kalıcılık testinden elde ettikleri puanlar t-testi analizi yapılarak test edilmiştir. Yapılan test analizi sonucunda kontrol grubu ile deney grubunun kalıcılık testi sonuçlarına ilişkin puanlar Tablo 5'te sunulmuştur.

Tablo 5. Kalıcılık Testi Puanları

\begin{tabular}{lccccccc}
\hline Test Adı & Çalışma Grupları & $\mathbf{n}$ & $\overline{\boldsymbol{x}}$ & Ss & $\mathbf{d f}$ & $\mathbf{t}$ & $\mathbf{p}$ \\
\hline \multirow{2}{*}{ Kalıcılık Testi } & Kontrol Grubu & 10 & 56,0 & 7,15 & 18 & 8,630 & .00 \\
\hline$N=20$ & Deney Grubu & 10 & 87,0 & 13,84 & & & \\
\hline
\end{tabular}

Tablo 5 incelendiğinde deney ve kontrol gruplarındaki öğrencilerin kalıcılık testinden elde ettikleri puanlar t-testi analizi yapılarak test edilmiştir. Yapılan test analizi sonucunda kontrol grubu ile deney grubunun kalıcılık testi sonuçlarına ilişkin puanlar karşılaştırıldığında deney grubundaki öğrencilerin kalıcılık testinden elde ettikleri puanların ortalaması kontrol grubundaki öğrencilerin ortalamalarından anlamlı bir biçimde farklı olduğu görüldüğü tespit edilmiştir. Deney grubunun kalıcılık testinden elde ettiği ortalama puan $86(\bar{x}=86)$, kontrol grubundaki öğrencilerin kalıcılık testi puan ortalamaları ise $56(\overline{\mathrm{x}}=56)$ olarak tespit edilmiştir. Başka bir ifadeyle deney ve kontrol gruplarının kalıcılık ortalamaları arasındaki farklılık istatistiki olarak anlamlı bulunmuştur $(\mathrm{p}<.05)$.

Deney ve kontrol grubu öğrencilerinin ön test puanlarına göre düzeltilmiş kalıcılık testi puanları arasındaki farklılığı sınamak amacıyla Ancova analizi uygulanmıştır. Öğrencilerin ön test puanlarına göre düzeltilmiş kalıcılık testi puan ortalamaları Tablo 6'da sunulmuştur.

Tablo 6. Grupların Ortalamaları ve Düzeltilmiş Ortalamaları

\begin{tabular}{lccc}
\hline Grup & n & Ortalama & Düzeltilmiş Ortalama \\
\hline Deney Grubu & 10 & 87,00 & 86,23 \\
Kontrol Grubu & 10 & 44,5 & 45,27 \\
\hline
\end{tabular}

Tablo 6 incelendiğinde kalıcılık testi için öğrencilerin puanları deney grubunda 87,00 kontrol grubunda ise 44,5 olarak tespit edilmiştir. Öğrencilerin elde ettiği bu puanlar incelendiğinde deney grubundaki öğrencilerin ortalamalarının kontrol grubundaki öğrencilerin ortalamalarına göre daha yüksek olduğu görülmektedir. Öğrencilerin kalıcılık testi düzeltilmiş ortalamaları incelendiğinde, deney grubunun ortalamas1 86,23 kontrol grubunun ortalaması ise 45,27 olduğu görülmektedir. Deney ve 
kontrol grubundaki ögrencilerin kalıc1lık testi ortalamaları arasında istatistiki olarak anlamlı bir fark olup olmadığına yönelik Ancova değerleri Tablo 7'de sunulmuştur.

Tablo 7. Ön Test Puanlarına Göre Düzeltilmiş Kalıcılık Test Puanlarının Gruba Göre Ancova Sonuçları

\begin{tabular}{lcccccc}
\hline Varyans Kaynağı & $\begin{array}{c}\text { Kareler } \\
\text { Toplamı (KT) }\end{array}$ & SD & $\begin{array}{c}\text { Kareler } \\
\text { Ortalaması (KO) }\end{array}$ & $\boldsymbol{f}$ & p & $\begin{array}{c}\text { Eta } \\
\text { Kare }\end{array}$ \\
\hline Model & $9840,154^{\mathrm{a}}$ & 10 & 984,015 & 6,447 & .005 & .878 \\
Terleyince & 141,438 & 1 & 141,438 & .927 & .361 & .093 \\
Geyik ile Kaplan & 11,158 & 1 & 11,158 & .073 & .793 & .008 \\
Adsız Çeşme & 38,119 & 1 & 38,119 & .250 & .629 & .027 \\
Doğuran Kazan & 0,598 & 1 & .598 & .004 & .951 & .000 \\
Ağustos Böceği ve Karınca & 157,677 & 1 & 157,677 & 1,033 & .336 & .103 \\
Kitabım & 0,360 & 1 & .360 & .002 & .962 & .000 \\
Atatürk & 0,769 & 1 & .769 & .005 & .945 & .001 \\
Gökçen Kız & 135,270 & 1 & 135,270 & .886 & .371 & .090 \\
Mevsimler & 113,882 & 1 & 113,882 & .746 & .410 & .077 \\
GRUP & $\mathbf{6 9 6 1 , 3 4 7}$ & $\mathbf{1}$ & $\mathbf{6 9 6 1 , 3 4 7}$ & $\mathbf{4 5 , 6 1 2}$ & $\mathbf{. 0 0 0}$ & $\mathbf{. 8 3 5}$ \\
Hata & 1373,596 & 9 & 152,622 & & & \\
Toplam & 97675,000 & 20 & & & & \\
Düzeltilmiş Toplam & 11213,750 & 19 & & & & \\
\hline$p<.05$ & & & & & &
\end{tabular}

Tablo 7'deki Ancova sonuçları incelendiğinde deney grubu ve kontrol grubundaki öğrencilerin ön test puanlarına göre düzeltilmiş kalıcılık test puanları arasında anlamlı bir fark olduğu tespit edilmiştir $(\mathrm{F}(1,19)=45,61, \mathrm{p}<.05)$. Buna bağlı olarak grupların düzeltilmiş ön test puanları arasında yapılan Bonferroni testi sonuçlarına göre deney grubunda yer alan öğrencilerin kalıcılık ortalamalarının $(\overline{\mathrm{x}}=86,23)$, kontrol grubunda yer alan öğrencilerinkinden $(\overline{\mathrm{x}}=45,27)$ daha yüksek olduğu tespit edilmiştir. Hesaplanan $\eta^{2}$ değerinin .84 olduğu görülmektedir. Deney grubundaki öğrencilerin kontrol grubundaki öğrencilere oranla kalıcılık testinde daha başarılı olduğu tespit edilmiştir.

\subsection{Demografik Değişkenlere Göre Ön Test ve Kalıcılık Testi Sonuçlarına İlişkin Bulgular}

Tablo 8. Katılımcıların Cinsiyetine Göre Kalıcıllk Testi Puanlarının Karşılaştırılması

\begin{tabular}{|c|c|c|c|c|c|c|c|}
\hline Boyut & Cinsiyet & $\mathbf{n}$ & $\overline{\boldsymbol{x}}$ & SD & df & $\mathbf{t}$ & $\mathbf{p}$ \\
\hline \multirow{2}{*}{ Terleyince } & $\mathrm{K}_{1 \mathrm{Z}}$ & 9 & 55,5556 & 21,85813 & \multirow{2}{*}{18} & \multirow{2}{*}{.186} & \multirow{2}{*}{.85} \\
\hline & Erkek & 11 & 53,6364 & 23,77929 & & & \\
\hline \multirow{2}{*}{ Geyik ile Kaplan } & $\mathrm{K}_{1 \mathrm{z}}$ & 9 & 60,0000 & 22,36068 & \multirow{2}{*}{18} & \multirow{2}{*}{.728} & \multirow{2}{*}{.48} \\
\hline & Erkek & 11 & 50,9091 & 31,44982 & & & \\
\hline \multirow{2}{*}{ Adsız Çeşme } & $\mathrm{K} 1 \mathrm{z}$ & 9 & 54,4444 & 26,03417 & \multirow{2}{*}{18} & \multirow{2}{*}{-.234} & \multirow{2}{*}{.82} \\
\hline & Erkek & 11 & 57,2727 & 27,60105 & & & \\
\hline \multirow{2}{*}{ Doğuran Kazan } & $\mathrm{K}_{1 \mathrm{Z}}$ & 9 & 47,7778 & 23,33333 & \multirow{2}{*}{18} & \multirow{2}{*}{.044} & \multirow{2}{*}{.97} \\
\hline & Erkek & 11 & 47,2727 & 27,23634 & & & \\
\hline \multirow{2}{*}{$\begin{array}{l}\text { Ağustos Böceği ve } \\
\text { Karınca }\end{array}$} & $\mathrm{K}_{1 \mathrm{Z}}$ & 9 & 46,6667 & 20,00000 & \multirow{2}{*}{18} & \multirow{2}{*}{.058} & \multirow{2}{*}{.96} \\
\hline & Erkek & 11 & 47,2727 & 25,72583 & & & \\
\hline
\end{tabular}


Tablo 8. (Devam) Katılımcıların Cinsiyetine Göre Kalıcılık Testi Puanlarının Karşılaştırılması

\begin{tabular}{|c|c|c|c|c|c|c|c|}
\hline Boyut & Cinsiyet & $\mathbf{n}$ & $\overline{\boldsymbol{x}}$ & SD & df & $\mathbf{t}$ & $\mathbf{p}$ \\
\hline \multirow{2}{*}{ Kitabım } & $\mathrm{K}_{1 \mathrm{z}}$ & 9 & 57,7778 & 33,82964 & \multirow{2}{*}{18} & \multirow{2}{*}{.818} & \multirow{2}{*}{.42} \\
\hline & Erkek & 11 & 43,6364 & 41,77864 & & & \\
\hline \multirow{2}{*}{ Atatürk } & $\mathrm{K}_{1 \mathrm{Z}}$ & 9 & 46,6667 & 24,49490 & \multirow{2}{*}{18} & \multirow{2}{*}{.104} & \multirow{2}{*}{.92} \\
\hline & Erkek & 11 & 45,4545 & 26,96799 & & & \\
\hline \multirow{2}{*}{$\begin{array}{l}\text { Gökçen K1z } \\
\text { Çeşmesi }\end{array}$} & $\mathrm{K}_{1 \mathrm{Z}}$ & 9 & 32,2222 & 30,73181 & \multirow{2}{*}{18} & \multirow{2}{*}{$-1,108$} & \multirow{2}{*}{.32} \\
\hline & Erkek & 11 & 46,3636 & 31,07176 & & & \\
\hline \multirow{2}{*}{ Mevsimler } & $\mathrm{K}_{1 \mathrm{z}}$ & 9 & 57,7778 & 25,38591 & \multirow{2}{*}{18} & \multirow{2}{*}{.227} & \multirow{2}{*}{.82} \\
\hline & Erkek & 11 & 54,5455 & 35,87858 & & & \\
\hline \multirow{2}{*}{ Kalıcılık Testi } & Kız & 9 & 66,6667 & 29,26175 & \multirow{2}{*}{18} & \multirow{2}{*}{.214} & \multirow{2}{*}{.83} \\
\hline & Erkek & 11 & 69,0909 & 21,42641 & & & \\
\hline
\end{tabular}

Tablo 8 incelendiğinde öğrencilerin cinsiyetine göre ön test ve kalıcılık testi puanlarının anlamlı bir farklılık gösterip göstermediğini test etmek amacıyla bağımsız örneklem t-testi uygulanmıştır. Yapılan analiz sonucunda öğrencilerin cinsiyetine göre ön test ve kalıcılık testi puanlarının istatistiki olarak anlamlı bir biçimde farklılaşmadığ 1 tespit edilmiştir ( $\mathrm{p}>.05)$.

Tablo 9. Aile Mevcuduna Göre Kalıcılık Testi Puanlarının Karşılaştırılması

\begin{tabular}{|c|c|c|c|c|c|c|}
\hline Boyut & Mevcut & $\mathbf{n}$ & Ort. & SS & $f$ & $\mathbf{p}$ \\
\hline \multirow{3}{*}{ Terleyince } & 3-5 Kişi & 2 & 36,2500 & 11,87735 & \multirow{3}{*}{.771} & \multirow{3}{*}{.59} \\
\hline & 6-8 Kişi & 17 & 39,0000 & 11,97219 & & \\
\hline & 9-11 Kişi & 19 & 30,0000 & 14,14214 & & \\
\hline \multirow{3}{*}{ Geyik ile Kaplan } & 3-5 Kişi & 2 & 55,0000 & 25,63480 & \multirow{3}{*}{.264} & \multirow{3}{*}{.93} \\
\hline & 6-8 Kişi & 17 & 56,0000 & 18,97367 & & \\
\hline & 9-11 Kişi & 19 & 45,0000 & 7,07107 & & \\
\hline \multirow{3}{*}{ Adsız Çeşme } & 3-5 Kişi & 2 & 48,7500 & 21,00170 & \multirow{3}{*}{1,681} & \multirow{3}{*}{.20} \\
\hline & 6-8 Kişi & 17 & 59,0000 & 16,63330 & & \\
\hline & 9-11 Kişi & 19 & 50,0000 & 42,42641 & & \\
\hline \multirow{3}{*}{ Doğuran Kazan } & 3-5 Kişi & 2 & 52,5000 & 13,88730 & \multirow{3}{*}{1,891} & \multirow{3}{*}{.16} \\
\hline & 6-8 Kişi & 17 & 55,0000 & 17,15938 & & \\
\hline & 9-11 Kişi & 19 & 30,0000 & 14,14214 & & \\
\hline \multirow{3}{*}{$\begin{array}{l}\text { Ağustos Böceği ve } \\
\text { Karınca }\end{array}$} & 3-5 Kişi & 2 & 43,7500 & 13,02470 & \multirow{3}{*}{.746} & \multirow{3}{*}{.60} \\
\hline & 6-8 Kişi & 17 & 54,0000 & 21,18700 & & \\
\hline & 9-11 Kişi & 19 & 50,0000 & 14,14214 & & \\
\hline \multirow{3}{*}{ Kitabım } & 3-5 Kişi & 2 & 50,0000 & 17,72811 & \multirow{3}{*}{1,340} & \multirow{3}{*}{.30} \\
\hline & 6-8 Kişi & 17 & 46,0000 & 13,49897 & & \\
\hline & 9-11 Kişi & 19 & 50,0000 & 14,14214 & & \\
\hline \multirow{3}{*}{ Atatürk } & 3-5 Kişi & 2 & 52,5000 & 14,88048 & \multirow{3}{*}{.846} & \multirow{3}{*}{.54} \\
\hline & 6-8 Kişi & 17 & 47,0000 & 18,88562 & & \\
\hline & 9-11 Kişi & 19 & 40,0000 & 28,28427 & & \\
\hline \multirow{3}{*}{$\begin{array}{l}\text { Gökçen K1z } \\
\text { Çeşmesi }\end{array}$} & 3-5 Kişi & 2 & 37,5000 & 15,81139 & \multirow{3}{*}{2,323} & \multirow{3}{*}{.10} \\
\hline & 6-8 Kişi & 17 & 56,0000 & 19,55050 & & \\
\hline & 9-11 Kişi & 19 & 55,0000 & 7,07107 & & \\
\hline \multirow{3}{*}{ Mevsimler } & 3-5 Kişi & 2 & 50,0000 & 16,03567 & \multirow{4}{*}{2,130} & \multirow{4}{*}{.12} \\
\hline & 6-8 Kişi & 17 & 56,0000 & 18,97367 & & \\
\hline & 9-11 Kişi & 19 & 50,0000 & 42,42641 & & \\
\hline \multirow{3}{*}{ Kalıcılık Testi } & 3-5 Kişi & 2 & 63,1250 & 24,48578 & & \\
\hline & 6-8 Kişi & 17 & 69,0000 & 26,54137 & \multirow[t]{2}{*}{.370} & \multirow[t]{2}{*}{.86} \\
\hline & 9-11 Kişi & 19 & 60,0000 & 21,21320 & & \\
\hline
\end{tabular}


Tablo 9 incelendiğinde araştırmaya katılan öğrencilerin kalıcılık testi puanlarının öğrencilerin ailedeki kişi sayısına göre (kalabalıklığa göre) farklılık gösterip göstermediğini tespit etmek amacıyla tek yönlü varyans analizi (Anova) yapılmış olup yapılan analizler sonucunda öğrencilerin kalıcılık testi puanlarının öğrencilerin ailelerinin kalabalık oluşuna göre istatistiki olarak anlamlı bir fark göstermediği tespit edilmiştir ( $>$ >.05).

Tablo 10. Ailede Başka Özel Eğitim Alan Bireylerin Olup Olmama Durumuna Göre Kalıcılık Testi Puanlarının Karşılaş̧tırlması

\begin{tabular}{|c|c|c|c|c|c|c|c|}
\hline Boyut & Durum & $\mathbf{n}$ & $\overline{\mathbf{x}}$ & SD & df & $\mathbf{t}$ & $\mathbf{p}$ \\
\hline \multirow{2}{*}{ Terleyince } & Evet & 2 & 30,0000 & 14,14214 & \multirow{2}{*}{18} & \multirow{2}{*}{-.883} & \multirow{2}{*}{.39} \\
\hline & Hayır & 18 & 37,7778 & 11,65966 & & & \\
\hline \multirow{2}{*}{ Geyik ile Kaplan } & Evet & 2 & 60,0000 & 28,28427 & \multirow{2}{*}{18} & \multirow{2}{*}{.388} & \multirow{2}{*}{.70} \\
\hline & Hayır & 18 & 53,8889 & 20,61949 & & & \\
\hline \multirow{2}{*}{ Adsız Çeşme } & Evet & 2 & 50,0000 & 42,42641 & \multirow{2}{*}{18} & \multirow{2}{*}{-.286} & \multirow{2}{*}{78} \\
\hline & Hayır & 18 & 54,4444 & 18,85618 & & & \\
\hline \multirow{2}{*}{ Doğuran Kazan } & Evet & 2 & 70,0000 & 14,14214 & \multirow{2}{*}{18} & \multirow{2}{*}{1,745} & \multirow{2}{*}{.10} \\
\hline & Hayır & 18 & 49,4444 & 15,89385 & & & \\
\hline \multirow{2}{*}{$\begin{array}{l}\text { Ağustos Böceği } \\
\text { ve Karınca }\end{array}$} & Evet & 2 & 50,0000 & 14,14214 & \multirow{2}{*}{18} & \multirow{2}{*}{.041} & \multirow{2}{*}{.97} \\
\hline & Hayır & 18 & 49,4444 & 18,30211 & & & \\
\hline \multirow{2}{*}{ Kitabım } & Evet & 2 & 30,0000 & 14,14214 & \multirow{2}{*}{18} & \multirow{2}{*}{$-1,952$} & \multirow{2}{*}{.07} \\
\hline & Hayır & 18 & 50,0000 & 13,71989 & & & \\
\hline \multirow{2}{*}{ Atatürk } & Evet & 2 & 50,0000 & 14,14214 & \multirow{2}{*}{18} & \multirow{2}{*}{.124} & \multirow{2}{*}{.90} \\
\hline & Hayır & 18 & 48,3333 & 18,23055 & & & \\
\hline \multirow{2}{*}{$\begin{array}{l}\text { Gökçen Kız } \\
\text { Çeşmesi }\end{array}$} & Evet & 2 & 50,0000 & 28,28427 & \multirow{2}{*}{18} & \multirow{2}{*}{.115} & \multirow{2}{*}{.91} \\
\hline & Hayır & 18 & 48,3333 & 18,86484 & & & \\
\hline \multirow{2}{*}{ Mevsimler } & Evet & 2 & 70,0000 & 14,14214 & \multirow{2}{*}{18} & \multirow{2}{*}{1,349} & 20 \\
\hline & Hayır & 18 & 51,1111 & 19,06302 & & & .20 \\
\hline$V$ le l1 Tot: & Evet & 2 & 65,0000 & 21,21320 & 10 & 045 & 07 \\
\hline Kalicilk Iesti & Hayır & 18 & 65,8333 & 25,16124 & 18 & -.045 & .91 \\
\hline
\end{tabular}

$\overline{N=20}$

Tablo 10 incelendiğinde öğrencilerin ailesinde başka bireylerin özel eğitim alıp almadığına göre kalıcılık testi puanlarının anlamlı bir farklılık gösterip göstermediğini test etmek amacıyla bağımsız örneklem t-testi uygulanmıştır. Yapılan analiz sonucunda öğrencilerin ailesinde başka bireylerin özel eğitim alıp almama durumuna göre kalıcılık testi puanlarının istatistiki olarak anlamlı bir biçimde farklılaşmadı $\mathrm{g} 1$ tespit edilmiştir (p>.05).

\subsection{Metin Türlerinin Ön Test Puanlarının Karşılaştırılması}

Araştırmanın beşinci alt problemini oluşturan "Deney ve kontrol grubundaki öğrencilerin okuduğunu anlama ön testindeki puanlarına uygun olarak metin türlerinin ön test puanları anlamlı bir biçimde farklılaşmakta mıdır?" sorusuna ilişkin veriler Tablo 11'de sunulmuştur. 
Tablo 11. Metin Türlerinin Ön Test Puanlarl

\begin{tabular}{|c|c|c|c|}
\hline Metin Türü & Metin Adı & $\frac{\text { Kontrol Grubu }}{\bar{x}}$ & $\frac{\text { Deney Grubu }}{\bar{x}}$ \\
\hline \multirow{4}{*}{ Bilgilendirici Metinler } & Terleyince & 35,0 & 39,0 \\
\hline & Atatürk & 47,0 & 50,0 \\
\hline & Ort & 41,00 & 44,50 \\
\hline & Ort. & \multicolumn{2}{|c|}{42,75} \\
\hline \multirow{6}{*}{ Hikâye Edici Metinler } & Geyik ile Kaplan & 51,0 & 58,0 \\
\hline & Doğuran Kazan & 47,0 & 56,0 \\
\hline & Ağustos Böceği ve Karınca & 47,0 & 52,0 \\
\hline & Gökçen Kız Çeşmesi & 46,0 & 51,0 \\
\hline & Ort. & \multirow{2}{*}{\multicolumn{2}{|c|}{51,00}} \\
\hline & & & \\
\hline \multirow{4}{*}{ Şiir Metinleri } & Adsız Çeşme & 51,0 & 57,0 \\
\hline & Kitabım & 47,0 & 49,0 \\
\hline & Mevsimler & 50,0 & 56,0 \\
\hline & Ort. & 51,66 & 54,00 \\
\hline
\end{tabular}

Öğrenci merkezli bir yaklaşımla hazırlanan Türkçe Dersi Öğretim Programı, öğrencilerin öğretmenleri eşliğinde derslere aktif olarak katılmalarını, öğrenme güçlüğü çeken öğrencilerin dahi derslere katılımlarını zorunlu kılmaktadır (Epçaçan \& Erzen, 2008). 2018 Türkçe Dersi Öğretim Programı'nda yer alan metin türlerinin karşılaştırılmasına dair Tablo 11. incelendiğinde çalışma grubundaki öğrencilerin ortalamalarının bilgilendirici metinler türünde en düşük olduğu (KG $\bar{x}=41,00$; DG $\bar{x}=44,50)$, şiir metinleri türünde ise en yüksek olduğu (KG $\bar{x}=49,33$; DG $\bar{x}=54,00)$ tespit edilmiştir. Hikâye edici metinlerde ise öğrencilerin ortalamalarının kontrol grubunda $\bar{x}=47,75$ deney grubunda ise $\bar{x}=54,25$ olduğu tespit edilmiştir.

\section{SONUÇ VE TARTIŞMA}

Günümüzde gelişen teknolojik gelişmeler hayatın her alanında olduğu gibi eğitim alanında da gelişmeleri ve yenileşmeyi beraberinde getirerek alternatif eğitim faaliyetlerinin ortaya çıkmasını sağlamıştır. Modern eğitim faaliyetleri ile beraber daha verimli ve kalıcı öğrenmeler sağlanmakta ve disiplinler arası çalışmaların önemi artmaktadır.

Son yıllarda internet ve bilişim teknolojilerinin gelişmesiyle beraber eğitim ortamlarındaki çeşitlilik de artmakta ve bu gelişmelerin eğitim teknolojileri ile bütünleşmesi için yoğun çaba sarf edilmektedir (Göksu \& Bolat, 2020, s. 141). Özel eğitim ihtiyacı olan hafif zihinsel gereksinimli 6. sınıf öğrencilerinin okuduğunu anlama becerilerini geliştirmede teknoloji destekli öğretimin ne düzeyde etkili olduğunu tespit etmek amacıyla gerçekleştirilen bu araştırmanın bulguları incelenerek değerlendirilmiştir.

Araştırmanın verilerinden hareketle elde edilen ön test bulgularına ilişkin aritmetik ortalamalar incelendiğinde; Terleyince metni, Geyik ile Kaplan metni, Adsız Çeşme metni, Doğuran Kazan metni, Ağustos Böceği ve Karınca metni, Kitabım metni, Atatürk metni, Gökçen Kız Çeşmesi metni, Mevsimler metni olarak tespit edilmiş ve deney grubu ile kontrol grubunun ön test puanları arasında anlamlı bir farklılık bulunamamıştır. Fakat öğrencilere uygulanan kalıcılık testi puanları 
karşılaştırıldığında deney grubu ile kontrol grubundaki öğrencilerin puanları arasında istatistiki olarak anlamlı bir fark olduğu görülmüştür.

Birbirine denk olan bu gruplardan, kontrol grubundaki öğrencilere ilgili metinler geleneksel öğretim yöntemleri ile sunulmuş olup deney grubundaki öğrencilere ise etkileşimli tahta aracıllı̆ı ile zenginleştirilmiş slaytlar, dijital resimler, videolar ve sözsüz fon müzikleri ile bu metinler sunulmuştur. Araştırma sonucunda deney grubundaki öğrencilerin kalıcılık testi puanlarının kontrol grubundaki öğrencilerin puanlarından daha yüksek olduğu görülmektedir. Gruplar diğer bütün değişkenler açısından birbirine denk olup sadece teknolojik donanım açısından ve eğitimin veriliş yol ve yöntemi açısından farklılaşmaktadır. Bütün değişkenler birbirine denk ancak teknolojik açıdan farklı olan grubun farklı sonuçlar elde etmesinde sınıf içi eğitim teknolojisinin etkili olduğu sonucuna varılmıştır.

Araştırma bulguları incelendiğinde öğrencilerin cinsiyetine göre ön test ve kalıcılık testi puanlarının anlamlı bir farklılık gösterip göstermediğini tespit etmek amacıyla bağımsız örneklem ttesti uygulanmıştır. Yapılan analiz sonucunda öğrencilerin cinsiyetine göre ön test ve kalıcılık testi puanlarının istatistiki olarak anlamlı bir biçimde farklılaşmadığı tespit edilmiştir.

Araştırma bulguları incelendiğinde araştırmaya katılan öğrencilerin ön test ve kalıcılık testi puanlarının öğrencilerin ailedeki kişi sayısına göre (kalabalıklığa göre) farklılık gösterip göstermediğini tespit etmek amacıyla yapılan tek yönlü varyans analizi (Anova) yapılmış olup yapılan analizler sonucunda öğrencilerin ön test ve kalıcılık testi puanlarının öğrencilerin ailelerinin kalabalık oluşuna göre istatistiki olarak anlamlı bir fark göstermediği tespit edilmiştir.

Öğrencilerin ailesinde başka bireylerin özel eğitim alıp almama durumuna göre araştırma bulguları incelendiğinde öğrencilerin ailesinde başka bireylerin özel eğitim alıp almama durumuna göre ön test ve kalıcılık testi puanlarının istatistiki olarak anlamlı bir biçimde farklılaşmadığ 1 tespit edilmiştir.

Şahin ve Bayramoğlu'na (2016) göre öğrencilere metinler aracılığıyla kazanımlar, ahlaki bilgiler, gelenek ve görenekler, dil bilgisi çalışmaları ve dil becerileri kazandırılabilmektedir. Yapılan bu çalışmada da öğrencilerin metin türleri ön test puanları karşılaştırıldığında deney grubu öğrencilerinin hikâye edici metinler türünde, kontrol grubu öğrencilerinin öğrencilerin şiir metinleri türünde, hem deney hem kontrol grubu öğrencilerinin şiir metinleri türünde başarılı oldukları ve her iki öğrenci grubunun da en az başarılı oldukları metin türlerinin bilgilendirici metinler oldukları; en başarılı alt türün ise hikâye edici metin türlerinin alt türü olan Geyik ile Kaplan masal metni olduğu, en az başarılı alt türün ise bilgilendirici metin türlerinin alt türü olan Terleyince anı metni olduğu tespit edilmiştir.

Bulgular bir bütün olarak incelendiğinde Türkçe dersi kapsamında yapılan bu araştırmanın okuduğunu anlama üzerindeki etkisi deney ve kontrol grubu öğrencileri aracılığıyla tespit edilmiştir. Bu tespitlere göre geleneksel öğretim yoluyla sunulan eğitim ile teknoloji destekli öğretim arasında her ne kadar süreç içerisinde farklılık görülmese de zamana karşı direnci ölçen kalıcılık testinde her iki grup arasında anlamlı bir farklılık olduğu anlaşılmaktadır. Bu durum kontrol grubu öğrencilerinin metinleri okuduğunu ama anlamlandıramadıklarını, aynı şekilde testlerin zamana karşı kalıcılık direnci ölçüldüğünde öğrencilerin kendilerine geleneksel öğretim yoluyla sunulan metinleri hatırlamakta zorlandıkları veya hatırlayamadıkları ortaya çıkmıştır. Deney grubu öğrencileri ise teknoloji destekli öğretim ile kendilerine sunulan slayt, video, fon müzik, dijital resim gibi daha fazla duyu organına hitap eden okuma metinlerini süreç içerisinde kontrol grubu öğrencileri gibi anlamlandıramadıkları fakat testlerin zamana karşı direnci ölçüldüğünde metinleri daha rahat hatılladıklarını ortaya çıkarmıştır. Bu 
durum aslında deney grubu öğrencilerinin süreç içerisinde metinleri anlamlandırdıklarını fakat performansa dönüştüremediklerini ortaya koymaktadır.

Yapılan benzer bir çalışmada öğrenme güçlüğü riski olan öğrencilerin akıcı okuma ve okuduğunu anlama becerilerinde zenginleştirilmiş okuma becerileri müdahale paketinin etkililiği araştırılmış ve araştırma sonucunda zenginleştirilmiş içerikler sunulan öğrenci grubunun okuma hızının artmasında, okuma hatasının azalmasında, prozodik okuma ve okuduğunu anlama becerilerinin gelişmesinde olumlu sonuçlar elde edilmiştir (Akın, 2020, s. 130). Başka bir çalışmada sınıf içi teknolojilerin özel öğretim öğrencilerinin sınıf içi öğrenmelerine olan etkisi araştırılmış ve öğrencilerin sınıf içi öğrenmelerinde teknolojinin öğrencilerin öğrenmelerine olumlu yönde katkı sağladığı saptamıştır (Bayrakdar ve Çuhadar, 2015, s. 187). Başka bir çalışmada katılımcıların sınıf içerisinde teknoloji kullanımına ilişkin tutumlarının genel olarak olumlu yönde olduğu ve teknolojinin sınıf içi öğrenmeleri kolaylaştırdığı sonucuna ulaşmışlardır (Dargut ve Çelik, 2014). Başka bir çalışmada özel öğrenme güçlüğü olan bir öğrencinin okuduğunu anlama becerisinin tahmin-inceleme-özetleme-örgütlemedeğerlendirme (TIÖD) okuduğunu anlama stratejisi ile geliştirilmesi amaçlanmıştır. Yapılan çalışmanın pilot uygulamasından elde edilen sonuçlara göre strateji öğretiminin kelime tanıma, okuduğunu anlama ve okuma düzeyine olumlu yönde etkisinin olduğu belirlenmiştir (Kaşdemir, 2020, s. 105). Başka bir çalışmada yapılandırmacı tasarım eğitim teknolojilerinin, öğrencilerin etkin ve aktif öğrenmesine katkıda bulunduğu ve öğrencilerin problem çözme becerilerinin gelişmesine olumlu katkılar sağladığ sonucuna ulaşmıştır (Özmen, 2004). Başka bir çalışmada ise çoklu ortam materyallerinin okuma yazma güçlüğü çeken ilkokul öğrencileri üzerindeki etkisi araştırılmış ve çoklu ortam okuma yazma materyallerinin okuma sürecine geleneksel yöntemlere göre daha fazla katkı sağladığı, yazma sürecine ise fazla katkı sağlamadığı tespit edilmiştir. Çalışma süreci sonucunda ise öğrencilerin okuma yazma hızlarının ölçümleri sonucunda okuma yazma hızlarında anlamlı bir farklılaşma olmadığ 1 tespit edilmiştir. Araştırma dahilinde okuma üzerinde olumlu, yazma üzerinde olumsuz sonuçlara ulaşılmıştır (Şahin, 2018, s. 81).

Yapılan araştırmanın sonuçlarından hareketle aşağıdaki önerilerde bulunulmaktadır:

- Araştırma sonucunun genellenebilmesi için daha büyük örneklem grubu ile benzer bir çalışma yap1labilir.

- Benzer bir araştırma diğer özel gereksinim grubundaki öğrenciler için de yapılarak teknoloji destekli öğretimin özel eğitime olan katkısı daha net bir biçimde ortaya konulabilir.

- Benzer bir araştırma dinleme, konuşma ve yazma becerilerine yönelik olarak yürütülebilir.

- Millî Eğitim Bakanlığına bu gibi çalışmalar proje olarak sunulup özel eğitim grubu öğrencilerinin etkinlikleri ve eğitim süreçleri çeşitlendirilebilir.

- Özel gereksinimi olan bireylerin öğrenme ihtiyaçlarına yönelik ihtiyaç analizi yapılarak, bu bireylerin eğitiminde öğrenme ortamlarının teknoloji destekli bir şsekilde tasarlanması sağlanabilir. 


\section{KAYNAKLAR}

Ağın Haykır, H., Kaplan, H., Kıryar, A., Tarakçı, R. ve Üstün, E. (2018). 5. sınıf Türkçe ders kitabı. Ankara: Millı̂ Eğitim Bakanlığı Yayınları.

Akın, U. (2020). Öğrenme güçlüğ̈̈ riski olan ögrrencilerin akıcı okuma ve okuduğunu anlama becerilerinde zenginleştirilmiş okuma becerileri müdahale paketinin etkililiği: Müdahaleye tepki modeli düzey-II yaklaşımı uygulaması (Yayımlanmamış doktora tezi). Gazi Üniversitesi, Eğitim Bilimleri Enstitüsü, Ankara.

Akkaya, A. (2013). Türkçe derslerinde ders kitabı dışında görsel öge kullanmaya ilişkin Türkçe öğretmenlerinin görüşlerinin incelenmesi. Turkish Studies, 8(9), 471-479. DOI: 10.7827/TurkishStudies.5562

Atak, A. O. (2019). İnsani değerler eğitimi. http://www.insanidegerleregitimi.com/sayfa.php?degerID=4 adresinden 11 Temmuz 2019 tarihinde alındı.

Ataşci, A. (2019). 4. sınıf Türkçe ders kitabı. Ankara: Koza Yayınları.

Bayrakdar, U. ve Çuhadar, C. (2015). İşitme engelliler okullarında bilgi ve iletişim teknolojilerinin öğretim amaçlı kullanımının incelenmesi. Trakya Üniversitesi Eğitim Fakültesi Dergisi, 5(2), 172-191.

Belet Boyacı, Ş. ve Güner Özer, M. (2019). Öğrenmenin geleceği: 21. yüzyıl becerileri perspektifiyle Türkçe dersi öğretim programları. Anadolu Journal of Educational Sciences International, 9(2), 708-738. DOI: 10.18039/ajesi.578170

Büyüköztürk, Ş. (2001). Deneysel desenler öntest-sontest kontrol grubu desen ve veri analizi. Ankara: Pegem A Yayıncilik.

Canbazoğlu Bilici, S. (2019). Örnekleme yöntemleri. Ankara: Pegem Akademi Yayınları.

Çakmak, M., Özdaş, F. ve Akın, M. A. (2020). Learning how to learn scale a study of validity and reliability. Educational Policy Analysis and Strategic Research, 15(3), 438-455. DOI: 10.29329/epasr.2020.270.21

Çakmak, M., Özdaş, F. ve Öter, Ö. M. (2017). Öğretmen görüşlerine göre ortaokul öğretim programlarındaki değerlerin kazandırılma düzeyinin incelenmesi. Asos Journal, 5(63), 193-206.

Çoban, S. (2012). Uzaktan ve teknoloji destekli eğitimin gelişimi. İstanbul: XVI. Türkiye’de İnternet Konferans1 Bildiri Kitabı.

Dağlarca, F. H. (2012). Bütün şiirleri 3. Ankara: Yapı Kredi Yayınları.

Dargut, T. ve Çelik, G. (2014). Türkçe öğretmeni adaylarının eğitimde teknoloji kullanımına ilişkin tutum ve düşünceleri. Ana Dili Eğitimi Dergisi, 2(2), 28-41. DOI: 10.16916/aded.04927

Demir, M. (2019). Fen bilimleri dersinde akıllı tahta kullanımının köy okullarında öğrencilerin akademik başarılarına, ögrendikleri bilgilerin kalıcılı̆̆ına ve derse yönelik tutumlarına etkisi (Yayımlanmamış yüksek lisans tezi). Niğde Ömer Halis Demir Üniversitesi, Niğde.

Epçaçan, C. ve Erzen, M. (2008). İlköğretim Türkçe dersi öğretim programının değerlendirilmesi. Journal of International Social Research, 1(4), 182-202.

Ertuna, S. (2019). 2. sinıf Tüm dersler süper kitap. İstanbul: Okyanus Yayıncılık.

Evran Acar, F. (2010). Sinıf öğretmenliği programından mezun olan öğretmenlerin Türkçe dersine ilişkin yeterliklerinin değerlendirilmesi. Türk Ĕgitim Bilimleri Dergisi, 8(1), 89-115.

Fraenkel, J. R. ve Wallen, N. E. (2006). How to design and evaluate research in education. Boston: McGraw-Hill.

Göçer, A. (2012). Dil-Kültür ilişkisi ve etkileşimi üzerine. Türk Dili, (729), 50-57.

Göksu, İ. ve Bolat, Y. (2020). Teknoloji kullanımı Türkiye'de öğrencilerin akademik başarılarını etkiliyor mu? Bir meta-analiz çalışması. Eğitim Teknolojisi Kuram ve Uygulama, 10(1), 138-176. DOI: 10.17943/etku.614505

Göksu, İ. ve Gülcü, A. (2016). Ortaokul ve liselerde uygulanan destekleme kurslarıyla ilgili öğretmen görüşleri. Bayburt Eğitim Fakültesi Dergisi, 11(1), 153-171.

Heinich, R., Molenda, M., Russell, J. D. ve Smaldino, S. E. (2002). Instructional media and technologies for learning. New Jersey: Pearson. 
Hiçyılmaz, Y.ve Kayserili, M. E. (2017). Görsel sanatlar dersinde akıllı tahta kullanımına ilişkin öğretmen görüşlerinin incelenmesi. Atatürk Üniversitesi Kazım Karabekir Ĕ̈itim Fakültesi Dergisi, 35, 56-75.

Kabakçı, I. ve Odabaşı, H. F. (2004). Teknolojiyi kullanmak ve teknogerçekçi olabilmek. Anadolu Üniversitesi Sosyal Bilimler Dergisi, 4(1), 19-27.

Kanar, N. (2009). Masal örnekleri. https:/www.liseedebiyat.com/index.php/ders-notlari/37-9-sinif-dl-veanlatim/1155-masal-oernekler.html adresinden 18 Temmuz 2019 tarihinde alındı.

Kaplan, G. ve Tekinarslan, İ. (2013). Zihinsel yetersizliği olan ve olmayan öğrencilerin astronomi kavramlarındaki bilgi düzeylerinin karşılaştırılması. Illköğretim Online, 12(2), 614-627.

Kaşdemir, B. (2020). Özel ögrenme güçlüğ̈̈ olan bir ögrencinin okuduğunu anlama becerisinin tahmin-incelemeözetleme-örgütleme-değerlendirme (TIÖD) okuduğunu anlama stratejisi ile geliştirilmesi (Yayımlanmamış yüksek lisans tezi). Zonguldak Bülent Ecevit Üniversitesi, Zonguldak.

Kuday, N. (2020). Okul yöneticilerinin teknoloji kaynakl strese ilişkin görüşlerinin çeşitli değişkenlere göre değerlendirilmesi (Yayımlanmamış yüksek lisans tezi). Harran Üniversitesi, Şanlıurfa.

La Fontaine, J. (2011). La Fontaine'den masallar-2. Ankara: Yap1 Kredi Yayınları.

Lee, M. ve Winzenried, A. (2009). The use of instructional technology in schools, lessons to be learned. Victoria: Acer.

Millî Eğitim Bakanlığı (2010). Özel ĕgitim hizmetleri tanıtım el kitabı. Ankara: Millî Eğitim Bakanlı̆̆ı.

Millî Eğitim Bakanlığı (2020). Özel eğitim hizmetleri yönetmeliği. Ankara: Millî Eğitim Bakanlığı. Erişim adresi: https://orgm.meb.gov.tr/www/mevzuat/icerik/608

Özdaş, F. ve Çakmak, M. (2018). Öğretmen adaylarının öğretmenlik uygulaması dersine ilişkin metaforik algıları. Uluslararası Türkçe Edebiyat Kültür Eğitim Dergisi, 7(4), 2747-2766.

Özdemir, R., Kisaç, B., Ünlü, E. ve Kaplan, G. (2020). The investigatıon of quality indicators of individualized education plan prepared in public schools. European Journal of Special Education Research, 6(1), 129141. DOI: $10.46827 /$ ejse.v6i1.3164

Özmen, H. (2004). Fen öğretiminde öğrenme teorileri ve teknoloji destekli yapılandırmacı (Constructivist) öğrenme. The Turkish Online Journal of Educational Technology, 3(1), 100-111.

Patton, M. (2014). Qualitative research \& evaluation methods: Integrating theory and practice. Thousand Oaks, United States: SAGE Publications Inc.

Subakan, Y. ve Koç, M. (2019). Özel eğitim gereksinimli bireylerin gelişim ve eğitimlerinde kullanılan mobil cihazlar ve yazılımlar. Bilim, Ĕgitim, Sanat ve Teknoloji Dergisi, 3(2), 51-61. DOI: 10.46328/seat.v3i2.29

Şahin, D. ve Bayramoğlu, C. D. (2016). 2015 Türkçe öğretim programının metin tür ve tema seçimi bakımından değerlendirilmesi. Turkish Studies, 11(3), 2095-2130. DOI: 10.7827/TurkishStudies.9289

Şahin, F. (2018). Çoklu ortam materyallerinin okuma-yazma güçlüğü çeken öğrencilerin okuma-yazma becerileri üzerideki etkisi (Yayımlanmamış yüksek lisans tezi). Amasya Üniversitesi, Amasya.

Şanal, S. Ö., Güler, T. D. ve Erdem, M. (2018). Özel eğitimde öğretim teknolojisi araştırmaları: Türkiye örneklemi. Ĕgitim Teknolojileri Okumaları. İçinde TOJET, 408-424.

Şirin, M. R. (2011). Doğuran kazan. İstanbul: Erdem Çocuk Yayınları.

Tezcan, M. (1996). Eğitim sosyolojisi. Ankara: Feryal Matbaası. 


\section{EXTENDED ABSTRACT}

As with all courses, technology-assisted education has been required to be used in Turkish and to increase the studies in this direction. The Turkish course is suitable for the interdisciplinary model and is directly or indirectly related to other courses. Today, special education units are being opened and increasing for children who need special education. This has brought with it the need for academic studies. It is important that these students, whose native language is Turkish, are raised in more competent and modern educational conditions.

This research was conducted to determine the effect of technology-supported education on improving reading comprehension skills of students who need special education. For this purpose, the effect of technology support on the level of understanding of secondary school 2nd grade (6th grade) students with mild mental retardation was tried to be tested. This study, designed in a mixed pattern, sought answers to the question "What is the impact of technology-assisted education on the comprehension skills of special education students?"

Technology plays an important role in the education of students with disabilities. Adapted and specially designed technologies have a huge impact on students' learning and potential. Students with disabilities, in particular, need special educational practices. Students with mental retardedness need highly structured learning environments because messages should be presented to these students in a context they are accustomed to or know. Students with hearing impedition, students with visual impedition, or students in other disability groups, all need different learning materials (Heinich, Molenda, Russell, \& Smaldino, 2002, p. 15).

Designed in a mixed-method, this research was carried out with quantitative and qualitative data from 20 secondary school students with mild mental illnesses. For experimental and control groups, texts of 9 genres, which are subtypes of informative, storytelling and poetry text genres in the 2018 Turkish Course Teaching Program, are presented to both the experimental group and the control group in weekly periods. From these equivalent groups, the relevant texts were presented to the students of the control group through traditional teaching methods and the students in the experimental group were presented with these texts through the interactive board. After the texts were processed, students were given a 5-question text evaluation scale prepared individually for each text. The tests were evaluated on a total of 100 points for each question to be calculated as 20 points. After the last test, with the help of the Presume Test conducted 2 weeks later, the level of meaning of the texts read by the students was tried to be determined by analysis method. After the Primality Test, the 5-question Application Evaluation Form, which was prepared to get the opinions of the experimental group students for technology-assisted education, was presented to the students and the answers to these questions were examined by content analysis method.

When the research findings were examined, there was no significant difference between the experimental group and the preliminary test scores of the students in the control group. However, compared to the persy test scores applied to the students as the final test, it was understood that there was a significant statistical difference between the test group and the scores of the students in the control group. As a result of the research, it was determined that the final test scores of the students in the experimental group were more than the scores of the students in the control group.

According to findings, although there is no difference in the process between the education offered through traditional education and technology-assisted education, it is understood that there is a 
significant difference between the two groups in the Perennity Test, which measures resistance to time. This situation has increased when control group students read texts but can't make sense of them, and in the same way that when the tests are measured in per lasting resistance to time, students find it difficult or unable to remember the texts art presented to them through traditional teaching. The students of the experimental group revealed that they could not make sense of the reading texts that appeal to more sensory organs such as slides, videos, background music, digital pictures presented to them through technology-assisted educational activities, but they remembered the texts more easily when the resistance of the tests was measured against time. This situation reveals that the students of the experimental group made sense of the texts in the process but could not convert them into performance.

In light of the research findings, it is recommended to encourage teachers to use learning environments and technologies that can positively affect in-class learning and to organize training programs on the use of assisting technology for teachers and employees with special needs. It is also recommended to continuously monitor the impact of in-class educational technologies on student learning, to prepare richer and inclusive e-content for in-class software. However, it is also suggested that special education courses should be applied compulsorily in teacher training programs. 